\title{
An Improved Method to Conjugation of KLH-Diazinon
}

\author{
Mohammad Reza Khakzad ${ }^{1}$, Farzin Hadizadeh ${ }^{2 *}$, Abdolreza Varasteh ${ }^{1}$, Maliheh Moghaddam², Mohammad \\ Saadatmandzadeh ${ }^{3}$ and Mojtaba Sankian ${ }^{2 *}$ \\ ${ }^{1}$ Department of Immunology, Islamic Azad University, Iran \\ ${ }^{2}$ Mashhad University of Medical sciences, Iran
}

${ }^{3}$ Ferdowsi University of Mashhad, Iran

Submission: August 20, 2018; Published: November 15, 2018

*Corresponding author: Mojtaba Sankian \& Farzin Hadizadeh, Bu-Ali Research Institute, Ferdossi Square, Bu-Ali Square, Mashhad, Iran

\begin{abstract}
Monoclonal antibodies are now widely used for hapten detection by immunoassay kits. The first and critical step in development of an immunoassay kit is selection and synthesis of a suitable hapten-carrier. Diazinon as a non-immunogenic hapten should be attached in an appropriate way to a carrier molecule. The suitable design of active hapten is an important stage and challengeable problem for monoclonal antibody production. This study indicates that our procedure for making an active hapten is time saving, easier and less expensive in comparison with previous study findings and, furthermore, resulting in production of a high affinity anti-diazinon monoclonal antibody.
\end{abstract}

Keywords: Hapten; Diazinon; Carrier; Conjugation

\section{Introduction}

The immunoassay techniques are recently used in the assay and detection of low molecular weight poisons, like the residue of organophosphate pesticides in agricultural and food products. The first and critical step in development of an immunoassay kit is selection and synthesis of a suitable hapten[1].Traditionally, gas chromatography, high performance liquid chromatography and mass spectroscopy are validated techniques for the determination of small molecules, however, these methods are not cost effective and user-friendly[2].The immunoassay techniques such as enzyme-linked immunosorbent assay (ELISA) have been developed as a simple, rapid, and costeffective alternative to above mentioned techniques[3]. Diazinon is one of the organophosphate pesticides with wide application in agriculture that are toxic to humans[4].

Monoclonal antibodies are now widely used for hapten detection by immunoassay kits. The application of immunization is essential as an adjunct to monoclonal antibody production to do so, diazinon as a hapten, should first be attached correctly to a carrier molecule[5]. The suitable design of hapten is an important stage for immunization in animal models to monoclonal antibody production against small molecules[6]. A precise attachment of the hapten to a carrier is very challenging and requires high skilled researchers. The chemical cross-linkers strongly influence a hapten structure and limit availability of its antigenic active sites leading to a loss of effective interaction between hapten and antibodies in immunoassay techniques[6].
Small organic molecules such as diazinon are non-immunogenic. Therefore, design and synthesis of suitable carrier conjugate is a high fundamental parameter for its immunoassays. Unfortunately, in most cases the complexity of hapten synthetic process, leads to the masking of its functional groups and so lowers titer and affinity of monoclonal antibodies against hapten structure. Another problem is selection of a suitable spacer between hapten and carrier. Conformational effects of the spacer arm on hapten most probably cause invalidity of some immunoassays. Furthermore, type and length of spacer arms and most noteworthy, attachment site is very critical and affect the affinity of the resulting antibodies[1].

Few cases have been reported regarding the correct attachments of a diazinon to carrier molecules. Unfortunately, the developed assays had low sensitivity and specificity for diazinon detection. Furthermore, one of the strong problems is selection of spacer with suitable length ( $\mathrm{n}=$ number of atoms) between hapten and carrier protein to prevent possible changes in electrostatic effects of hapten-protein conjugates and, hence, perturbation in the three-dimensional conformation of the hapten[6]. In previous studies for diazinon hapten synthesis, spacer arms such as 3-aminopropanol $(n=3)$ or 6 -aminocaproic acid $(n=6)$ have been used[7].

Commonly, two strategies are discussed for the design of diazinon hapten synthesis. One approach is linker attachment directly to the its aromatic ring[7]. In this strategy, the 
attachment of the hydrocarbon spacer arm to the oxygen atom of the diazinon aromatic ring has been used[8]. This approach is an easy synthesis pathway; however, it is suitable for production of polyclonal antibodies against diazinon[7]. The other approach is the connection of a spacer to the aromatic ring through thiophosphate moiety that is suitable for maximizing exposure of aromatic ring[9]. At first, this method was introduced by Heldman et al and was developed later by McAdam et al.\& Tae Lee $[5,9,10]$. Although, this strategy has difficult synthesis pathway, but it can be used for monoclonal antibody production against diazinon[8]. We encountered some difficulties in synthetizing the reactive hapten diazinon by McAdam [9,11] and Tae Lee [5] methods. So, we improved their method in order to optimize reaction yields. Herein, we described an effective synthesis of diazinon-linker (6-aminocaproic acid) conjugate, attached to the diazinon thiophosphate group (Figure 1). Finally, we have prepared conjugated diazinon (hapten)-KLH which could be useful as an immunogen.<smiles>COP(=S)(OC)Oc1cc(C)nc(C(C)C)n1</smiles>

(1)

Hapten Conjugate

(6)<smiles>Cc1cc(O)nc(C(C)C)n1</smiles>

(2)
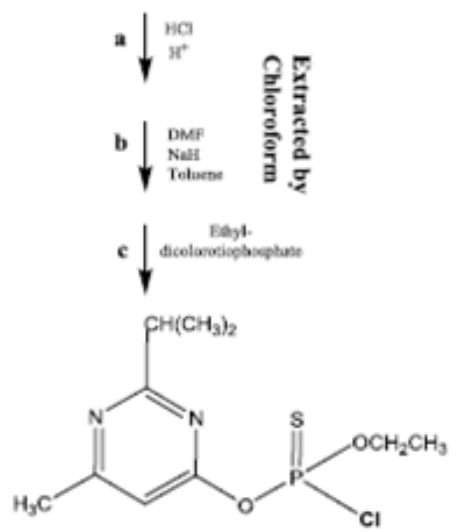

(3)

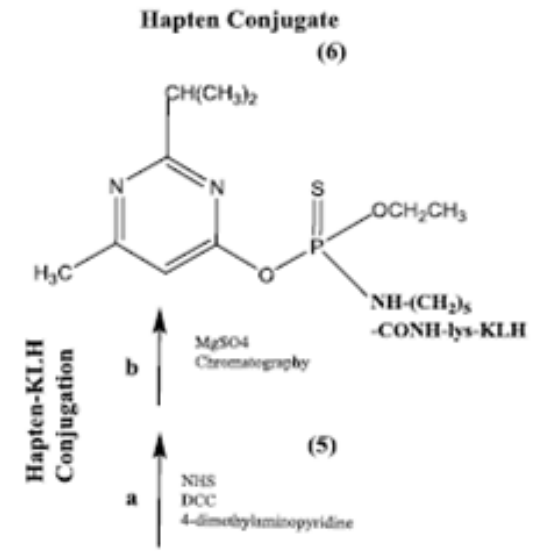

Figure 1: Diazinon Hapten Synthesis.

\section{Material and Methods}

\section{Buffers and solutions}

The following buffers were employed: PBS, $10 \mathrm{mM}$ phosphate buffer, $137 \mathrm{mM} \mathrm{NaCl}, 2.7 \mathrm{mM} \mathrm{KCl}, \mathrm{pH} 7.4$; carbonate-bicarbonate buffer, pH 9.6; 1 and 2NHydrochloric acid; chloroformpetroleum-methanolether(30:70:1); chloroform- ethyl acetate (30:70).

\section{Chemicals and apparatus}

Sodium hydride $(\mathrm{NaH})$, ethyl dichlorothio phosphate, 6aminocaproic acid, N-hydroxy succinimide (NHS), dichloro methane, 4-dimethyl aminopyri dine, N, N-dicy clohexyl carbodiimide (DCC), Keyhole limpet hemocyanin (KLH), were purchased from Sigma Aldrich (USA). Technical diazinon was gifted by Farad Company, Iran.

All the other reagents, including $\mathrm{KOH}$, anhydrous dimethylformamide (DMF), Toluene, $\mathrm{MeOH}, \mathrm{EtOH}$, silica gel/ hexane/ethyl acetic acid (200:65:7), Sephadex G-25, MgSO4, Fatty acid free bovine serum albumin, were of the highest quality available from commercial sources. Dialysis membrane (cut off $12000 \mathrm{Da}$ ) was obtained from Himedia Laboratories (India).

The Chemical reactions were monitored and purified by thinlayer chromatography (TLC) plates (Silica Gel 60 F 254, Merck 
Germany) eluting by chloroform-petroleum ether, methanol (30:70:1) solution and detected with a UV-transilluminator at wavelength of $365 \mathrm{~nm}$. H NMR spectra were run on Bruker spectrometer $(300 \mathrm{MHz})$ using TMS as an internal standard. UV spectra were taken on a CE9500 Cecil Spectrophotometer (England).

\section{Hapten synthesis}

Preparation of pyrimidone [2]: To prepare Pyrimidone intermediate [2], Technical diazinon 1 (23g) dissolved in $4 \mathrm{ml}$ of EtOH70\%, containing 50mg KOH, mixed and refluxed for 6 hours in $100^{\circ} \mathrm{C}$ under stirring.The reaction mixture was neutralized with $2 \mathrm{~N} \mathrm{HCl}$. Afterwards, pyrimidone [2] was extracted from the reaction mixture by addition of an equal volume of, chloroform in petroleum ether $(1: 9)(\times 2)$. The extract was vacuum-dried for $1 \mathrm{~h}$ at $40-45{ }^{\circ} \mathrm{C}$ to give $6.4280 \mathrm{~g}$ (yield of $55.6 \%$ ) of pyrimidone 2. The $1 \mathrm{H}-\mathrm{NMR}$ spectrum was then recorded. $1 \mathrm{H}$ NMR (CDCl3): $\delta$ $6.74(1 \mathrm{H}, \mathrm{s}, \mathrm{H}-\mathrm{py}), 2.93(1 \mathrm{H}, \mathrm{m}, \mathrm{J}=6.9, \mathrm{CH}), 2.30(3 \mathrm{H}, \mathrm{s}, \mathrm{py}-\mathrm{CH} 3)$, $1.33(6 \mathrm{H}, \mathrm{d}, \mathrm{C} \mathrm{H} 3)$.

Preparation of 0-Ethyl 0- [6-methyl-2-(1-methylethyl)pyrimidinyl] phosphorochloridothioate [3]: Next, Pyrimidone [2] (150mg, 0.98mmol) dissolved in $1 \mathrm{~mL}$ anhydrous DMF. Sodium hydride ( $\mathrm{NaH}, 60 \mathrm{mg}, 2.5 \mathrm{mmol})$ was dissolved into anhydrous toluene $(5 \mathrm{~mL})$ and added spontaneously to pyrimidone [2] solution. The mixtures were stirred for $15 \mathrm{~min}$ at RT. Salt sodium of 2 was prepared and ethyl dichlorothiophosphate was added $(140 \mu \mathrm{L})$ and stirred $(\mathrm{rpm}=100)$ at RT for 3 days. Then, the product was isolated by a TLC method with chloroform-ethyl acetate-methanol (30:70:1) to give oily $164.64 \mathrm{mg}, 0.56 \mathrm{mmol}$ (yield of 57\%) of 3 . The $1 \mathrm{H}-\mathrm{NMR}$ spectrum was then recorded.1H NMR (CDCl3): $\delta 6.73$ (1H, s, H- py), 4.47 (2H, q, CH2O), $3.15(1 \mathrm{H}$, m, CH), 2.53(3H, s, py-CH3), 1.37 (3H, t, CH3), 1.32(6H, d, CH3).

Preparation of 0-Ethyl 0-[6-methyl-2-(1-methylethyl)pyrimidinyl] N-(4-carboxypentyl) phosphorami dothioate[4]: A stirred solution of $100 \mathrm{mg}(0.34 \mathrm{mmol})$ of 3 in $0.3 \mathrm{~mL}$ of $\mathrm{MeOH}$ cooled in an ice-water bath was added dropwise to a solution of $50 \mathrm{mg}(0.9 \mathrm{mmol})$ of $\mathrm{KOH} .53 \mathrm{mg}(0.41 \mathrm{mmol})$ of 6-aminocaproic acid in $1 \mathrm{~mL} \mathrm{MeOH}$ was added and stirred for 15 min at RT. After stirring, to transfer the product [4] from aqueous phase to organic phase, the mixture was filtered and acidified with adding $1 \mathrm{~N} \mathrm{HCl}(2 \mathrm{ml})$ extracted with $2 \mathrm{ml}$ of chloroform The organic extract was dried over $\mathrm{MgSO} 4$, and concentrated in a rotary evaporator at $40-45^{\circ} \mathrm{C}$ to about $500 \mu \mathrm{l}$ and then purified by chromatography on silica-gel column eluting with hexane-ethyl acetate-acetic acid (200:65:7). A yellow oil (95mg, $0.24 \mathrm{mmol}, 71.7 \%$ yield)and stored at $-20^{\circ} \mathrm{C}$ until used. The $1 \mathrm{H}-\mathrm{NMR}$ spectrum was then recorded.1H NMR (CDCl3): $\delta$ 11.5(1H, bs, COOH), 6.31 (1H, s, py), 4.07 (2H, m, CH2O), 3.72 (3H, m, NHCH2), 3.14(1H, m, CH) , 2.54(3H, s, py-CH3), 2.25 (2H,m, CH2CO2), $1.55-1.20(9 \mathrm{H}, \mathrm{m}, \mathrm{CH} 2, \mathrm{CH} 3)$.

Preparation of Hapten active ester [5]: For immunization purposes, the carboxylic acid group of the above prepared Hapten [4] was covalently attached to amino groups of carrier protein
(KLH or OVA), using NHS and DCC as an activating ester reagent. Briefly, NHS, N-hydroxysuccinimide (11 mg, 0.0095mmol) dissolved in $1.5 \mathrm{~mL}$ dichloromethane and Hapten $(40 \mathrm{mg}$, $0.10 \mathrm{mmol})$, 4-dimethylaminopyridine $(1.1 \mathrm{mg}, 0.0087 \mathrm{mmol})$, and DCC, N, N-dicyclohexylcarbodiimide (20 mg, $0.095 \mathrm{mmol}$ ) were added to it. The reaction mixture was incubated for $4 \mathrm{~h}$ at RT with stirring. Then filtered to remove the dicyclohexylurea, and the solvent was evaporated under reduced pressure at 40 $50^{\circ} \mathrm{C}$ to give crude yellow oily active ester [5]. This crude product was used in the next step without any further purification.

Preparation of Hapten KLH conjugate [6]: Crude activated hapten [5] was dissolved in anhydrous DMF (1ml). A solution of carrier protein (KLH) in $800 \mu \mathrm{L}, 0.1 \mathrm{M}$ Borate buffer (pH 9), was added dropwise to 5 solution. Immediately, $2 \mu \mathrm{L}$ of $2 \mathrm{~N} \mathrm{NaOH}$ was added. The mixture was stirred overnight at $4^{\circ} \mathrm{Cand}$ then centrifuged for $5 \mathrm{~min}$ at $10000 \mathrm{rpm}$ to remove any precipitate. Finally, KLH-hapten conjugate 6 were separated from uncoupled haptens by dialysis.The reaction solution was dialyzed using dialysis membrane (cut-off $12 \mathrm{KDa}$, Himedia, India) against PBS (10mM phosphate buffer, $137 \mathrm{mM} \mathrm{NaCl}, 2.7 \mathrm{mM} \mathrm{KCl}, \mathrm{PH} 7.4$ ) at $4^{\circ} \mathrm{C}$ with 3 changes per day for 2 days. The maximum absorption of native carrier was at $280 \mathrm{~nm}$ and it was found to be $414 \mathrm{~nm}$ in conjugate.

\section{Results and Conclusion}

This study is an effort to modify the synthetic process in preparation of diazinon hapten (Figure 1). Mc Adam and then Yang Tae Lee have previously reported method for preparation of diazinon hapten. In their method diazinon [1] is converted to pyrimidone intermediate [2] which is later is converted to chlorinated intermediate [3]. The latter is subsequently linked to 6-aminocaproic acid to produce [4]. Acid derivative is activated by NHS to give active ester [5] of hapten.Purification of each product was performed by recrystallization and / or column chromatography. And finally, active ester is conjugated to suitable carrier protein such as KLH to give [6]. We repeated the method exactly as described previously. The major problem we encountered during our work was insufficient product yield for in each step and so we could not get enough active ester as our finished product. So, we have used an improved and modified approach in developing diazinon hapten conjugates. At the first stage in preparation of 2 we omitted crystallization step and after evaporation of organic phase we used the oily residue 2 without any further purification. In the preparation of 3 and 4 we did not change the procedure. In the next step in preparation of active ester 5 we deleted the final purification process of 5 by column chromatography and used crude 5 directly in the next step of carrier protein conjugate 6 preparation. This approach was significantly successful in an increased production. After conjugation of 5 to carrier protein, the purification process by dialysis bag was performed to delete any small molecule impurity, including unreacted active ester 5 and acid derivative 4 from reaction mixture. The overall yield of our process was significantly increased, and we isolated carrier protein conjugate 6 in enough quantity. 
Due to deleting final time-consuming crystallization and column chromatography procedure the overall reaction time in our study was relatively shorter than that of McAdam and others. The setting of column chromatography usually takes a lot of time and it is a relatively expensive technique. The yield reported by Lee for column chromatography of active ester 5 was relatively low (28\%). As it was mentioned above, we repeated the method exactly as described previously and had low yields. Therefore, we attempted to replace it by purification of carrier protein conjugate 6 through dialysis. Of course, this did not affect our results and we got the final product 6 with a less expensive and easier way.

This study involved an improvement in immunoassay method by using monoclonal antibody against haptenic structure. The preparation of specific antibodies has a lot of complexity using an immunizing hapten. The synthesis of the immunizing hapten has been the most important key in monoclonal antibody production. Developing immunoassay technology is often expensive, timeconsuming and challengeable for researchers. Nevertheless, we well know that we are not allowed to do any major modifications in the hapten synthesis procedure. Some attempts have been reported regarding production of monoclonal antibody against diazinon but none of them were successful.

The structure of carrier conjugate was confirmed through comparing UV maximum absorption of native KLH and conjugate and a shifting from 280 to $414 \mathrm{~nm}$ was observed. Although, there are many factors that influence on making a monoclonal antibody, one of the most important of these factors is correct hapten synthesis. The sensitivity of our monoclonal antibody detected was found to be $10-100 \mathrm{pg} / \mathrm{ml}$ (data patented 139650140003001715 , Iran).This was significantly lower than that reported by Lee et al. [5](4.0ng/ml).

In conclusion, we can say that our reported procedure for hapten synthesis was time saving, easy and less expensive, resulting in production of diazinon monoclonal antibody with high affinity.

\section{References}

1. Kim YJ, Cho YA, Lee HS, Lee YT, Gee SJ (2003) Hammock BD. Synthesis of haptens for immunoassay of organophosphorus pesticides and effect of heterology in hapten spacer arm length on immunoassay sensitivity. Analytica Chimica Acta 475(1): 85-96.

2. Xu ZL, Deng H, Deng XF, Yang JY, Jiang YM, et al. (2012) Monitoring of organophosphorus pesticides in vegetables using monoclonal antibody-based direct competitive ELISA followed by HPLC-MS/MS. Food chemistry 131(4): 1569-1576.

3. Gonzalez TA, Kim H, Gee S, Last J, Hammock B, et al. (2007) Polyclonal antibody-based noncompetitive immunoassay for small analytes developed with short peptide loops isolated from phage libraries. Analytical chemistry 79(23): 9191-9196.

4. Sullivan JJ, Goh KS (2000) Evaluation and validation of a commercial ELISA for diazinon in surface waters. J Agric Food Chem 48(9): 40714078.

5. Lee EK, Kim YJ, Park WC, Chung T, Lee YT (2005) Monoclonal antibodybased enzyme-linked immunosorbent assays for the detection of the organophosphorus insecticide diazinon. Analytica chimica acta 530(1): 143-153.

6. XuZL, Wang H, Shen YD, Nichkova M, Lei HT, etal. (2011) Conformational changes of hapten-protein conjugates resulting in improved broadspecificity and sensitivity of an ELISA for organophosphorus pesticides. Analyst 136(12): 2512-2520.

7. Brun EM, Garces GM, Escuin E, Morais S, Puchades R, et al. (2004) Assessment of novel diazinon immunoassays for water analysis. Environmental science \& technology 38(4): 1115-1123.

8. Mercader JV, Primo J, Montoya A (1995) Production of high-affinity monoclonal antibodies for azinphos-methyl from a hapten containing only the aromatic moiety of the pesticide. Journal of Agricultural and Food Chemistry 43(11): 2789-2793.

9. McAdam D, Skerritt J (1993) Synthesis of organothiophosphate antigens for the development of specific immunoassays. Australian Journal of Chemistry 46(7): 959-967.

10. Heldman E, Balan A, Horowitz O, Ben ZS, Torten M (1985) A novel immunoassay with direct relevance to protection against organophosphate poisoning. FEBS Lett 180(2): 243-248.

11. Beasely H, McAdam D, Larkin K, Ferguson B, Bushway R, et al. (1997) Laboratory and field enzyme-immunoassays for diazinon and their application to residue analysis in lanolin, water, and fruit juice. Bulletin of environmental contamination and toxicology 59(3): 375-382.

\section{Your next submission with Juniper Publishers will reach you the below assets}

- Quality Editorial service

- Swift Peer Review

- Reprints availability

- E-prints Service

- Manuscript Podcast for convenient understanding

- Global attainment for your research

- Manuscript accessibility in different formats

( Pdf, E-pub, Full Text, Audio)

- Unceasing customer service

Track the below URL for one-step submission https://juniperpublishers.com/online-submission.php 